\title{
THE EFFECT OF CURRENT RATIO, DEBT TO EQUITY RATIO, TOWARD RETURN ON ASSETS (CASE STUDY ON CONSUMER GOODS COMPANY)
}

\author{
Hantono $^{1}$ \\ ${ }^{1}$ Accounting Study Program, Prima Indonesia University, Jl. Belanga No.1 Simp. Ayahanda, Medan, 20118, \\ Indonesia
}

Corresponding e-mail: hantono_78@yahoo.com

\begin{abstract}
This study aims to detect the effect liquidity ratio, leverage ratio and profitability on consumer goods companies listing on the Indonesia Stock Exchange 2014 - 2017. The object of this study is all consumer goods companies listing on the Indonesia Stock Exchange which publishes audited financial statements for fiscal year 2014 - 2017, which amounted to 24 (twenty four) companies. The sampling technique is by using purposive sampling method where the sample is determined based on certain criteria determined by the researcher and has limitations in terms of generalization. The sample of research is 42 (forty two companies) Data collection method using documentation method Data analysis technique used is descriptive quantitative analysis using current ratio, debt to equity ratio and return on assets. Keywords: current ratio, debt to equity ratio, return on assets
\end{abstract}

JEL Classification : G30,G32,G39

Article info:

Received 15 November 2018

Revised 19 December 2018

Accepted 28 December 2018

Available online 31 December 2018

\section{INTRODUCTION}

People always fulfill their daily needs by utilizing all kinds of resources that have been provided by nature, from water, plants, animals, all kinds of rocks. Natural resources that cannot be used directly or commonly called raw goods can be processed into finished goods until they can be utilized directly. In processing raw materials, it also requires a number of supporting resources such as human resources, machine resources and others. The process of processing raw goods into finished goods using these supporting resources is generally called manufacturing. There is a variety of manufacturing industries that we can see on the Indonesia Stock Exchange. The Indonesia Stock Exchange (IDX) is a capital market for various long-term financial instruments that can be traded, either in the form of debt or equity. IDX plays a major role in the country's economy.

Manufacturing sector is a promising choice in helping Indonesia's economic growth rate today. Consumer Goods Industry is included in the Manufacturing sector. Therefore, Consumer Goods industry is required to always maintain or increase the company's profit in order to encourage the country's economy. In order to maintain and increase company's profit, additional investment is required such as expanding its business into the country and abroad. Usually companies seeking additional funds in the form of investments will issue a number of securities such as bonds or shares to sell to the public.

Many previous researches has examined the relationship between liquidity ratios and indicators of financial performance or liquidity ratios and profitability ratios such as Bolek and Wilinski (2012) found a relationship between the quick ratio and return on assets. While Akter and Mahmud, (2014) conclude that there is no significant relationship between current 
ratio and return on assets. Priya and Nimalathasan (2013) found that the current ratio and cash ratio are significantly associated with return on assets. Ruziqa (2013) and Vayanos and Wang (2012) confirmed the liquidity ratios have positive significant effect on return on assets. Saleem and Rehman, (2011) and Khidmat and Rehman (2014) indicated a relationship between liquidity ratios and return on assets. This study was conducted to see the consistency of previous researchers, moreover, there are differences in the ratio used, as well as the object of research and thus have different results.

\section{LITERATURE REVIEWS}

Current Ratio. Hanafi and Abdul Halim (2009: 202), current ratios is calculated by dividing current asset with current liabilities. This ratio indicates how much cash that a company owns, and all the asset that can be converted to cash within a year, compare to its total liabilities that will mature in short term (not more than 1 year). According to Sofyan (2009:301), higher (current ratio) ratio of current asset compare to its current liabilities, refers to a better ability for company to pay off its short term debts. The indicator uses to measure liquidity in this research is current ratio (CR), which mathematically is calculated by dividing current assets with current liabilities.

$$
\text { Current ratio }=\frac{\text { Current assets }}{\text { Current liabilities }} \times 100 \%
$$

Debt to Equity Ratio. Darsono and Ashari (2010 : 54 - 55), debt to equity ratio (DER) is one ratio leverage or solvency. Solvability ratio is the ratio for knowing ability company in paying liability if the company liquidated. This ratio is also called the leverage ratio namely assessing the limits of the company in borrowing money. Horne and Wachowicz (2009 : 438),debt to equity ratio (DER) shows the extent to which debt funding is used when compared to equity funding. Sophisticated lenders and institutional investors certainly analyze the amount of fixed financial charges andevaluate financial risk in keeping with the ability of the firm to service these charges. However,individual investors may judge financial risk more by book value proportions of debt and equity. There may or may not be a reasonable correspondence between the ratio of debt to equity and the amount of fixed charges relative to the firm's cash-flow ability to service thesecharges. Some firms may have relatively high ratios of debt to equity but substantial cash-flowability to service debt.

$$
\text { Debt to equity ratio }=\frac{\text { Total debt }}{\text { Total equity }} \times 100 \%
$$

Return on Assets. Sugiono and Untung (2016: 68), return on assets (ROA) measures the rate of return from business on all existing assets or this ratio describes the efficiency of the funds used in the company. According to Murhadi (2015: 64), return on assets reflects how much return is generated on every rupiah of money invested in assets. According to Harahap (2015: 305), return on assets describes asset turnover measured from sales volume. The bigger the ratio the better. This means that assets can spin faster and earn profits. According to Jusuf (2014: 78), the formula for calculating return on assets (ROA) is:

$$
\text { ROA }=\frac{\text { Net income }}{\text { Total assets }} \times 100 \%
$$

Current Ratio Toward Return on Assets. Current Ratio (CR) is the ratio between current assets with current liabilities (Mamduh and Halim, 2014: 75). CR or current ratio is a 
true indicator of corporate liquidity, since the calculation considers the relative relationshipbetween current assets and current liabilities for each company (Syamsudin, 1985 in Wibowo and Pujiati, 2011). CR high can provide good information to potential investors. This will have an effect on investor interest in investing, resulting in increased current assets. The higher the current ratio shows the higher profit change (Kuswadi 2005: 79). Wibowo and Pujiati, 2011) concluded that the current ratio partially positively affects earnings changes. A study by Sari et al. (2018) showed that current ratio had a significant positive effect on return on assets, and so did Saragih, et al. (2015), Sofie, et al. (2015), Suyono and Gani (2017) and Qurays et al. (2018). On the contrary, Supardi et al. (2016) showed that current ratio had no effect on return on assets, so did Hersandy, et al. (2017), Ambarwati, et al. (2015). While Akter and Mahmud, (2014) conclude that there is no significant relationship between current ratio and return on assets. Priya and Nimalathasan (2013) found that the current ratio and cash ratio are significantly associated with return on assets. Ruziqa (2013) and Vayanos and Wang (2012) confirmed the liquidity ratios have positive significant effect on return on assets. Saleem and Rehman, (2011) and Khidmat and Rehman (2014) indicated a relationship between liquidity ratios and return on assets.

$H_{1}=$ Current Ratio effect significantly to Return on assets

Debt to Equity Ratio Toward Return on Assets. Debt to Equity Ratio (DER) is the ratio between total liabilities to total equity (Darsono and Ashari, 2005: 55) or the amount of current liabilities and long-term debt to equity. DER provides an overview of the capital structure owned by the company, so it can be seen the level of risk of uncollectible debt by investors. High DER has a bad impact on the company's performance because the higher the debt rate means the greater the interest burden which means less profit. In contrast, low DER levels show better performance, because it leads to higher returns. A study by Suyono and Gani (2017) demonstrated that debt-to-equity ratio had no effect on return on assets. Fadilah et al. (2017) showed that debt-to-equity ratio had no effect on profitability, as proxied by return on assets. Qurays et al. (2017) demonstrated that debt-to-equity ratio had an effect on profitability, as proxied by return on equity. A study by Utami (2016) showed that debt-toequity ratio had a significant positive effect on return on assets.

$\mathrm{H}_{2}=$ Debt to equity ratio effect significantly to Return on assets.

\section{RESEARCH METHOD}

\subsection{Data}

There are two variables in this research:

1. Dependent variable. Dependent variable in this study is return on assets.

2. Independent variable. Independent variable in this study is current ratio, debt to equity ratio.

\subsection{Sample}

This type of research uses quantitative approach, with a goal to investigate certain population or sample. Data used in this research is secondary data in the form of financial report in consumer goods company which consecutively listed in Indonesia Stock Exchange year $2014-2017$. The population of this research is all consumer goods company listed in Indonesia Stock Exchange year 2014 - 2017. Table 1 presents the sample of this study which obtained using purposive sampling on consumer goods company year 2014-2017. 
Table 1. Sample

\begin{tabular}{clc}
\hline No & \multicolumn{1}{c}{ Criteria } & Amount \\
\hline 1. & Consumer goods company listed in Indonesia Stock Exchange between 2014 & 42 \\
& -2017 \\
2. & $\begin{array}{l}\text { Consumer goods company not publishing financial report consecutively } \\
\text { between 2014-2017 }\end{array}$ & $(8)$ \\
3. & Consumer goods company not having positive revenue between 2014-2017 & $(10)$ \\
\hline Total Sample & $\mathbf{2 4}$ \\
\hline
\end{tabular}

\subsection{Method of analysis}

Dependent variable in this research is return on assets. shows the ability of a company to generate income with all assets effectively. This ratio is an important ratio existing in profitability ratio. Independent variables of this study are current ratio and debt to equity ratio. Current ratio is subject to certain limitations we must be aware of a high current ratio generally indicates a very strong, safe liquidity position, it might also indicate that the firm has too much old inventory that will have to be written off and too many old account receivable that may turn into bad debts. To a creditor, particularly a short-term creditor such as a supplier, the higher the current ratio is the better. Debt to Equity Ratio (DER) reflects the company's ability to meet all of its obligations if the company is facing bankruptcy (Solvency). Debt to Equity Ratio (DER) is the ratio between total debt held by the company with total shareholders' equity.

Multicollinearity test. According to Ghozali (2018:107-108), multicollinearity test is conducted to determine if there are any correlation among independent variables in a regression model. A valid regression model should not contain any correlation among independent variables. The key measurement to detect the existence of multicollinearity, are by seeing the value of tolerance and variance inflation factor (VIF) of each independent variable. If the value of tolerance is more than (>) 0,10 and VIF level for each independent variable is less than $(<) 10$, then are no indication of multicollinearity within the data.

Autocorrelation. According to Ghozali (2018 : 111 - 112), the purpose of autocorrelation test is to examine if there are any correlation exist between residuals in $t$ period and period t-1 in a linear regression model. A good regression model should be free from autocorrelation indication. The method uses to detect autocorrelation in this research is Durbin Watson test.

Heteroscedasticity test. According to Ghozali (2018 : $137-138)$, heteroscedasticity test is conducted to detect the difference of residual variance between observations or collected data in a regression model. If there is no difference on residual variance, then it indicates homoscedasticity where data can be considered valid. There are two methods can be used in detecting the existence of heteroscedasticity: scatterplot graphic and glejser test. Glejser test will conduct regression of the absolute residual value toward independent variable. If the independent variable is significantly influencing the dependent variable statistic, it indicates heteroscedasticity. The criteria of measurement can be done by coefficient significant, which indicates no heteroscedasticity if the significant value is more than $(>) 0,05$.

Coefficient of Determination (Adjusted $\mathbf{R}^{\mathbf{2}}$ ). Coefficient of determination (Adjusted $\mathrm{R}^{2}$ ) essentially measures how far the ability of the model explaining variations in the dependent variable. The value of determination coefficient is between zero and one. A lower value of Adjusted $\mathrm{R}^{2}$ indicates a limited ability of independent variables to explain dependent variable. Contrary, if Adjusted $\mathrm{R}^{2}$ is high or closer to one, it means independent variables of the research can provide most of the information needed to predict the variation of dependent variable. 
Data analysis method. This method is used when the type of relationship being examined is dependence, variables being predicted is one dependent variable and several independents variables in single relationship, and the measurement scale of dependent variable is in metric (Hair et al, 2010). The model equation of this study noted as follows:

$$
\mathrm{Y}=\alpha+\beta_{1} \mathrm{X}_{1}+\beta_{2} \mathrm{X}_{2}+\varepsilon
$$

where, $\mathrm{Y}$ is Return on Assets, $\alpha$ is constant, $\beta$ is coefficient of variables, $\mathrm{X}_{1}$ is Current Ratio, and $\mathrm{X}_{2}$ is debt to equity ratio.

Simultaneous Test (F- Test). The purpose of F Test is to examine whether there all independent variable in the research simultaneously impacting the dependent variable. The interpretation of $\mathrm{F}$ Test result can be done based on the criteria as stated as follow: (a) if $\mathrm{F}$ count $>\mathrm{F}$ table or probability $<$ significant value $(\mathrm{Sig} \leq 0.05)$ then the hypothesis is accepted, this means that simultaneously the independent variable has a significant influence on the dependent variable; and (b) if $\mathrm{F}$ count $<\mathrm{F}$ table or probability $>$ significant value $(\mathrm{Sig} \geq 0.05)$ then the Hypothesis is rejected, this means that simultaneously the independent variable does not have a significant effect on the dependent variable.

Partial Test (t- Test). The purpose of t-test is to examine whether independent variable individually have impact on dependent variable. According to (Ghozali, 2018), the interpretation of t-test result can be done thru observation of significant value of independent variable compare to the designed alpha, which is five percent $(5 \%)$. If the t-significance ( $\mathrm{p}$ value) is less than $(<) 0.05$, then $\mathrm{H} 0$ is rejected and $\mathrm{H} 1$ is accepted instead, which indicates that there are significant impact of independent variables on dependent variable.

\section{RESULTS AND DISCUSSION}

\subsection{Results}

Multicollinearity test. Multicollinearity test is conducted to examine whether there is a correlation among independent variable in a regression model, which is detected by observing its tolerance and variance inflation factor (VIF). If the tolerance $>0,10$ or VIF < 10 , it can be concluded that there is no correlation exist in this model. Table 2 presents result of the multicollinearity test for this study.

Table 2. Multicollinearity Test

\begin{tabular}{ccccc}
\hline & & \multicolumn{3}{c}{ Collinearity Statistics } \\
\cline { 3 - 5 } & Model & Tolerance & VIF \\
\hline \multirow{2}{*}{1} & CR & & 0.984 & 1.016 \\
& DER & & 0.984 & 1.016 \\
\hline
\end{tabular}

Dependent variable is ROA

Table 2 shows that result of calculation of tolerance value is there is no independent variables that have tolerance value of less than 0.10 which means there is no correlation between variables.

Autocorrelation test. Autocorrelation test aimed to examine whether there is correlation between variables from one-time period $(t)$, with the previous period $(t-1)$. One of the most popular approach to detects the presence of autocorrelation is by using Durbin Watson test. The details from Durbin Watson table where " $\mathrm{k}$ " is 2 (variables excluding dependent variable) and $\mathrm{N}$ is 24 , while value of $\mathrm{dL}$ and $\mathrm{dU}$ are: (1) $\mathrm{dL}$ is 1.1878; (2) dU is 1.5464 ; (3) 4- $\mathrm{dL}$ is 2.8122 ; and (4) $4-\mathrm{dU}$ is 2.4536. 
Table 3. Autocorrelation test

\begin{tabular}{|c|c|c|c|c|c|}
\hline Model & $\mathbf{R}$ & $\begin{array}{c}\mathbf{R} \\
\text { Square }\end{array}$ & $\begin{array}{l}\text { Adjusted R } \\
\text { Square }\end{array}$ & $\begin{array}{l}\text { Std. Error of the } \\
\text { Estimate }\end{array}$ & $\begin{array}{l}\text { Durbin- } \\
\text { Watson }\end{array}$ \\
\hline 1 & $0.325^{\mathrm{a}}$ & 0.106 & 0.086 & 0.10217 & 2.031 \\
\hline
\end{tabular}

From table 3, it can be concluded that there is no correlation because it match the criteria for Durbin Watson test where $\mathrm{dU}<\mathrm{dw}<4-\mathrm{dU}$ or $1.5464<2.031<2.4536$.

Heteroscedasticity Test. Heteroscedasticity test is used to test whether the variance of errors from a regression is dependent on the values of the independent variables in a linear regression model. To examine heteroscedasticity, the most commonly use approaches is Glejser test. If the independent variable is statistically significant in influencing the dependent variable, it indicates heteroscedasticity. The criteria of measurement are: if significant value is $>0,05$, it indicates no heteroscedasticity exist in the regression model.

Table 4. Glejser test

\begin{tabular}{|c|c|c|c|c|c|c|c|}
\hline \multirow{2}{*}{\multicolumn{2}{|c|}{ Model }} & \multicolumn{2}{|c|}{ Unstandardized Coefficients } & \multicolumn{2}{|c|}{ Standardized Coefficients } & \multirow[b]{2}{*}{$\mathbf{t}$} & \multirow[b]{2}{*}{ Sig. } \\
\hline & & $\mathbf{B}$ & Std. Error & Beta & & & \\
\hline 1 & Constant & 0.080 & 0.009 & & & 8.808 & 0.000 \\
\hline & $\mathrm{CR}$ & -0.002 & 0.001 & & -0.168 & -1.594 & 0.114 \\
\hline & DER & 0.001 & 0.003 & & 0.046 & 0.434 & 0.665 \\
\hline
\end{tabular}

Dependent Variable : abs_res_1

Based on the result of table above, all independent variables have significance value higher than 0,05 . It means heteroscedasticity does not exist in this regression model.

Coefficient of Determination (Adjusted $\mathbf{R}^{\mathbf{2}}$ ). Coefficient of Determination $\left(\mathrm{R}^{2}\right)$ is interpreted as the proportion or percentage of the variance in the dependent variable that is predictable from the independent variable. The value of coefficient of determination is between zero to one $(0 \leq \mathrm{R} 2 \leq 1)$. If $\mathrm{R}^{2}$ value is higher (approximately 1$)$ then it concludes that independent variable $(\mathrm{X})$ has much impact on dependent variable $(\mathrm{Y})$ which means that model is reliable in explaining the influence of independent variable to dependent variable or vice versa.

Table 5. Coefficient of determination test

\begin{tabular}{ccrrr}
\hline Model & $\mathbf{R}$ & R Square & Adjusted R Square & Std. Error of the Estimate \\
\hline 1 & $0.325^{\text {a }}$ & 0.106 & 0.086 & 0.10217 \\
\hline $\begin{array}{l}\text { Predictors: (Constant), DER, CR } \\
\text { Dependent Variable : ROA }\end{array}$ & & & \\
\end{tabular}

Based on Table 5, it can be seen that adjusted $\mathrm{R}$ square is 0,086 which means that there is $8,6 \%$ of the dependent variable (return on assets) can be explained by its independent variable which are current ratio $\left(\mathrm{X}_{1}\right)$, debt to equity ratio $\left(\mathrm{X}_{2}\right)$. While the other $91.4 \%$ is influenced by other variables which is not explained in this research model.

Data analysis method. Analysis of multi linear regression is used to explain the relationship between independent and dependent variable simultaneously and partially. Table 6 presents the result of multi linear regression analysis obtain from SPSS. 


\section{Table 6. Multi linear regression}

\begin{tabular}{|c|c|c|c|c|c|c|}
\hline & \multirow[b]{2}{*}{ Model } & \multicolumn{2}{|c|}{ Unstandardized Coefficients } & $\begin{array}{c}\text { Standardized } \\
\text { Coefficients }\end{array}$ & \multirow[b]{2}{*}{$\mathbf{t}$} & \multirow[b]{2}{*}{ Sig. } \\
\hline & & B & Std. Error & Beta & & \\
\hline 1 & (Constant) & 0.108 & 0.014 & & 7.944 & 0.000 \\
\hline & $\mathrm{CR}$ & 0.004 & 0.002 & 0.175 & 1.735 & 0.086 \\
\hline & DER & 0.012 & 0.004 & 0.297 & 2.937 & 0.004 \\
\hline
\end{tabular}

a. Dependent Variable: ROA

Based on Table 6, the regression model is:

$$
\mathrm{Y}=0,108+0,004 \mathrm{CR}+0,012 \mathrm{DER}
$$

where $\mathrm{Y}$ is the dependent variable (return on assets). The constant value of 0.108 means that if the independent variable which is CR, DER are assumed to be constant, then the value of $Y$ will be 0.108. Meanwhile regression coefficient associated with CR, DER are 0.004, 0.012 respectively, which mean that each one unit increases in the independent variable is also associate with same value of the regression coefficient. For example, if CR increase 1 unit, then it will impact to 0.004 unit of return on assets.

Simultaneous Test (F-Test). Simultaneous hypothesis testing which is also known as F-Test, is conduct in order to understand the significant level of impact that independent variables have toward dependent variable. By comparing $F$ statistic to $F$ value with alpha 0,05 , conclusion can be drawn whether a hypothesis is rejected or accepted.

\section{Table 7. F test}

\begin{tabular}{llrrrrr}
\hline Model & Sum of Squares & Df & Mean Square & F & Sig. \\
\hline 1 & Regression & 0.110 & 2 & 0.055 & 5.257 & $0.007^{\text {b }}$ \\
& Residual & 0.929 & 89 & 0.010 & & \\
& Total & 1.039 & 91 & & & \\
\hline
\end{tabular}

a. Dependent Variable: ROA

b. Predictors: (Constant), DER, CR

Based on Table 7, the result of F-Test, significance probability is 0,007 which is higher than alpha 0,05 significant level. It means that simultaneously, the independent variables have significant impact toward dependent variable.

Partial Test (t- Test). The use of $t$ test is to measure if independent variable in research model individually has significant impact on dependent variable. The interpretation of result of t-test can be done by comparison between significance level of the independent variable and designated alpha which is five percent, or else another t-test approach is by comparing the $\mathrm{t}$ statistic value from SPSS computation and $\mathrm{t}$-value from the table. If $\mathrm{t}$ statistic $<\mathrm{t}$ table, then $\mathrm{H}_{0}$ is accepted. Table 8 presents the result of $\mathrm{t}$ - test of this study.

Table 8. $t$ test

\begin{tabular}{|c|c|c|c|c|c|c|}
\hline & \multirow[b]{2}{*}{ Model } & \multicolumn{2}{|c|}{ Unstandardized Coefficients } & $\begin{array}{c}\text { Standardized } \\
\text { Coefficients }\end{array}$ & \multirow[b]{2}{*}{$\mathbf{t}$} & \multirow[b]{2}{*}{ Sig. } \\
\hline & & B & Std. Error & Beta & & \\
\hline 1 & Constant & 0.108 & 0.014 & & 7.944 & 0.000 \\
\hline & $\mathrm{CR}$ & 0.004 & 0.002 & 0.175 & 1.735 & 0.086 \\
\hline & DER & 0.012 & 0.004 & 0.297 & 2.937 & 0.004 \\
\hline
\end{tabular}

a. Dependent Variable: ROA 
The interpretation of $\mathrm{t}$-test result conducted for this research per independent variable will be compared to result from table, (significance level is 0,05 , total sample (n) is 24 , total variable ( $\mathrm{k})$ is 2 , degree of freedom $(\mathrm{df}=\mathrm{n}-\mathrm{k})$ is 22$)$ which amount of t table is 2.073 . Based on the table 8 , the significance $\mathrm{t}$ for current ratio is 0,086 which is higher than significance level $(\alpha)$ of 0,05 . Then $t$ statistic according to SPSS is 1.735 is lower than t table. If $t$ statistic $<\mathrm{t}$ table, then $\mathrm{H}_{0}$ is accepted, so this means that $\mathrm{CR}$ does not have significant impact on the dependent variable, return on assets for consumer goods companies listing on the Indonesia Stock Exchange which publishes audited financial statements for fiscal year $2014-2017$. For debt to equity ratio, the significance $\mathrm{p}$ is 2.937 which is lower than significant alpha 0,004 . Moreover, t statistic 2.937 is also lower than t table 2.073. Therefore, debt to equity ratio is considered significant factor of dependent variable, in other words significantly impact return on assets for consumer goods companies listing on the Indonesia Stock Exchange which publishes audited financial statements for fiscal year $2014-2017$.

\subsection{Discussions}

Current Ratio Toward Return on Assets. According to the conducted t test result for current ratio, $\mathrm{t}$ statistic $<\mathrm{t}$ table which is $1.735<2.073$ and significant $\mathrm{p} 0,086$ is above alpha 0,05 . Therefor research hypothesis is rejected, which means current ratio individually have not significant impact toward return on assets in consumer goods companies listing on the Indonesia Stock Exchange which publishes audited financial statements for fiscal year 2014 - 2017. Results of this study are consistent with those of previous study conducted by Supardi et al. (2016) showed that current ratio had no effect on return on assets, so did Hersandy, et al. (2017), Ambarwati, et al. (2015). Higher percentage of current ratio might indicate that company has better ability in term of paying off its short term debt with its current asset. However, considering the component in current ratio include other non-cash asset which might take longer time be converted. Thus investor might view current ratio as a misleading indicator of proving company liquidity which is why current ratio will not significant influence in the stock market.

Debt to equity Toward Return on Assets. According to the conducted t test result for debt to equity ratio, $t$ statistic $>t$ table which is $2.937>2.073$ and significant $p 0,004$ is lower alpha 0,05 . Therefore research hypothesis is accepted, which means debt to equity ratio individually have significant impact toward return on assets in consumer goods companies listing on the Indonesia Stock Exchange which publishes audited financial statements for fiscal year 2014 - 2017. The finding of this study is consistent with Qurays et al. (2017) where debt-to-equity ratio had an effect on profitability, as proxied by return on equity. Utami (2016) shows that debt-to-equity ratio had a significant positive effect on return on assets. Debt to equity ratio indicates the proportion of debt compare to its equity. Generally, if the percentage of ratio is too high, then company will have higher risk in bankruptcy in term of fulfilling all of its liability, thus researcher develop hypothesis that DER might have impact to return on assets.

\section{CONCLUSION}

Based on table 4, it can be seen that adjusted $\mathrm{R}$ square is 0,086 which means that there is $8,6 \%$ of the dependent variable (return on assets) can be explained by its independent variable which are current ratio $\left(X_{1}\right)$, debt to equity ratio $\left(X_{2}\right)$. While the other $91.4 \%$ is influenced by other variables which is not explained in this research model. Table 6 shows that the model fits for accounting for the effects of current ratio and debt-to-equity ratio on ROA, with a significance level of 0,007 which is higher than alpha 0,05 significant level. It means that simultaneously, the independent variables have significant impact toward dependent variable. This study has limitations in terms of the period under study and data 
available on the Indonesia Stock Exchange. Further studies are recommended to include variables related to solvency ratio and activity ratios.

\section{REFERENCES}

Akter, A., Mahmud, K. (2014), Liquidity-profitability relationship in Bangladesh banking industry. International Journal of Empirical Finance, 2(4), 112-134.

Ambarwati, N. Sagita, G.A. Yuniarta \& N.K. Sinarwati. (2015). Pengaruh Modal Kerja, Likuiditas, Aktivitas dan Ukuran Perusahaan terhadap Profitabilitas pada Perusahaan Manufaktur yang Terdaftar di Bursa Efek Indonesia. e-Journal Jurusan Akuntansi. Universitas Pendidikan Ganesha. Singaraja. Volume 3 No.1.

Bolek, M., Wilinski, W. (2012), The influence of liquidity on profitability of polish construction sector companies. Financial Internet Quarterly, 8(1), 77-89.

Darsono dan Ashari, (2010). Pedoman Praktis Memahami Laporan Keuangan, Andi, Yogyakarta.

Fadilah, N., E. Ghani \& E. Amaniyah. (2017). Pengaruh Quick Ratio, Inventory Turnover dan Debt to Equity Ratio Terhadap Rentabilitas pada Perusahaan Kabel yang Terdaftar di Bursa Efek Indonesia. Kompetensi. Vol. 11. No. 1. Pp : 89-108.

Ghozali,I.2018. Aplikasi Analisis Multivariate dengan Program SPSS 25, Badan Penerbit Universitas Diponegoro, Semarang.

Horne and Wachowicz (2009). Fundamentals of Financial Management. Retrieved from https://yamanfc.files.wordpress.com/2015/01/fundamentals-offinancialmanagement.pdf.

Hersandy, M., A. Hasan \& E. Savitri. (2017). The Effect Of Company Size, Company Growth, And Liquidity Towards Profitability With Capital Structure As a Moderating Variable (Case Study On The Banking Companies Listed On Indonesia Stock Exchange 2010-2014). Procuratio. Vol. 5. No. 3. Pp: 289 - 299.

Kuswadi. (2005). Meningkatkan Laba Melalui Pendekatan Akuntansi Keuangan dan Akuntansi Biaya. PT. Elex Media Komputindo, Jakarta.

Khidmat, W., Rehman, M. (2014), Impact of liquidity and solvency on profitability chemical sector of Pakistan. Economics Management Innovation, 6(3), 34-67.

Hanafi, dan Halim, A. (2014). Analisa Laporan Keuangan. Edisi ke empat, UPP STIM YKPN. Yogyakarta.

Harahap, Sofyan Syafri. (2009). Analisis Kritis Atas Laporan Keuangan. (Edisi 1). Jakarta: PT Raja Grafindo Persada.

Priya, K., Nimalathasan, B. (2013), Liquidity management and profitability: A case study of listed manufacturing companies in Sri Lanka. International Journal of Technological Exploration and Learning, 2(4), 135-151.

Murhadi, Werner R. (2015). Analisis Laporan Kuangan, Proyeksi dan Valuasi Saham.Jakarta: Salemba Empat

Ruziqa, A. (2013), The impact of credit and liquidity risk on bank financial performance: The case of Indonesian conventional bank with total asset above 10 trillion Rupiah. International Journal of Economic Policy in Emerging Economies, 6(2), 93-106.

Saleem, Q., Rehman, R. (2011), Impacts of liquidity ratios on profitability, interdisciplinary.Journal of Research in Business, 1(7), 78-91.

Saragih, M, Y. Siahaan, R. Purba \& Supitriyani. (2015). Pengaruh Current Ratio Terhadap Retun on Assets Pada Perusahaan Sektor Aneka Industri Yang Listing Di Bursa Efek Indonesia. Jurnal Financial. Vol. 1. No. 1. Juni 2015. Pp: 19 - 24. 
Sofie, A. Novita \& Bunga. (2015). Pengaruh Struktur Modal dan Likuiditas Terhadap Profitabilitas. e-Journal Akuntansi Trisakti. Volume. 2. Nomor. 1. Pp:13 - 28.

Supardi, H., H. Suratno \& Suyanto. (2016). Pengaruh Current Ratio, Debt to Asset Ratio, Total Asset Turnover dan Inflasi terhadap Return on Asset. JIAFE (Jurnal Ilmiah Akuntansi Fakultas Ekonomi). Vol. 2. No. 2. Pp : 16-27.

Sugiono, Arief dan Edy Untung. (2016). Panduan Praktis Dasar Analisa Laporan KeuanganEdisi Revisi. Jakarta : Grasindo.

Sari, N.P., Darmansyah \& Y. Murni. (2018). Pengaruh Current Ratio, Debt to Total Asset, Sales Growth terhadap Return on Asset setelah Diakuisisi dan Struktur Kepemilikan sebagai Pemoderasi. JIPI. Vol. 2. No. 1. Pp: $86-102$.

Suyono and E.A. Gani. (2017). Analysis of Liquidity Ratio, Activity Ratio, Working Capital Ratio and Solvency Ratio on The Profitability of Telecommunication Companies Listed on BEI (Period 2011-2016). Procuratio. Vol. 6. No. 1. Pp : 111-121.

Utami, D.A. (2016). Analisis Pengaruh Leverage dan Rasio Aktivitas terhadap Profitabilitas pada PT. Indofood Consumer Branded Products (CBP) Sukses Makmur, Tbk. Jurnal Sultanist. Vol. 4. No. 1. Pp : 44-51.

Vayanos, D., Wang, J. (2012), Liquidity and asset returns under asymmetric information and imperfect competition. The Review of Financial Studies, 25(5), 1339-1365.

Wibowo, H.A.dan Pujiati,D.(2011). Analisis rasio keuangan dalam memprediksi perubahan laba pada perusahaan real estate dan property Di Bursa Efek Indonesia (BEI) dan Singapura (SGX) (2011). The Indonesian Accounting Review, Volume 1, No. 2, pages $155-178$.

Qurays, A.A., J. Susyanti \& A. Rachmat. (2018). Pengaruh Financial Leverage, Operating Leverage dan Debt to Equity Ratio (DER) terhadap Profitabilitas Perusahaan. EJurnal Riset Manajemen Prodi Manajemen, Fakultas Ekonomi Unisma. 